\title{
How Meticulous Are You About Your Personal Items in the Hospital Environment? Attitude of Pediatricians
}

\author{
Hastane Ortamında Kişisel Eşyalarınızla Illgili Ne Kadar Titizsiniz? \\ Çocuk Hekimlerinin Tutumu
}

\author{
Nevin Hatipoğlu'(ID), Ateş Kara²(ID) \\ ${ }^{1}$ Clinic of Pediatric Infectious Diseases, Health Sciences University, Istanbul Bakırköy Dr. Sadi Konuk Training and Research Hospital, Istanbul, Turkey \\ ${ }^{2}$ Division of Pediatric Infectious Diseases, Department of Pediatrics, Hacettepe University School of Medicine, Ankara, Turkey
}

\section{Abstract}

Objective: The aim of this study was to investigate the attitudes and approaches of pediatricians regarding the cleaning of doctor's white coat, mobile phone and name badge.

Material and Methods: Pediatric infectious diseases specialist/subspecialist student, pediatrics/pediatric infectious diseases instructor (associate professor or professor) and pediatrics assistant working for at least 2 years were enrolled to the study. The number of doctor's white coat and the frequency of washing, the number of mobile phones they used and how they cleaned them, hospital badge usage, handling and cleaning attitudes were asked.

Results: Twenty-five instructors, 48 specialists and 27 assistants participated in the study. Although instructors and specialist physicians had more white coats than the assistants $(p=0.005)$, the frequency of coat washing did not differ between the groups of participants. Every physician had one mobile phone and nine physicians had two mobile phones. The use of name badges was most common in the resident physician group but the place of storage was not different between the groups. There was no difference between the physician groups in the preference of cleaning both mobile phones and badges.

Conclusion: As the seniority of the physicians increases, doctors have more white coats, but the washing habits do not change. There is lack of awareness of the need to clean personal items, such as cell phones and badges.

Keywords: Mobile phone, name badge, white coat
Öz

Giriş: Bu çalışmada çocuk doktorlarının doktor önlüğü, cep telefonu ve yaka kartının temizliği ile ilgili tutum ve yaklaşımlarının araştıııması amaçlanmıştır.

Gereç ve Yöntemler: Çalışmaya çocuk enfeksiyon hastalıkları uzmanları/yan dal uzmanlık öğrencileri, çocuk sağlığı ve hastalıkları/çocuk enfeksiyon hastalıkları öğretim görevlileri (doçent veya profesör) ve en az 2 yıldır çalışmakta olan çocuk sağlığı ve hastalıkları asistanları katıldı. Doktor önlüğü sayısı ve yıkama sıklığı, kullandıkları cep telefonu sayısı ve nasıl temizledikleri, hastane yaka kartı kullanımı, taşınması ve temizlik tutumları soruldu.

Bulgular: Çalışmaya 25 akademisyen, 48 uzman ve 27 asistan katıldı. Akademisyen ve uzman hekimler, asistanlara göre daha çok sayıda önlüğe sahip olmalarına rağmen $(p=0.005)$ önlük yıkama sıklığı katılımcı grupları arasında farklılık göstermiyordu. Her hekim bir adet, dokuz hekim ise iki adet cep telefonuna sahipti. Yaka kartı kullanımı en çok asistan doktor grubunda yaygındı fakat taşınma yeri gruplar arasında farklı değildi. Hem cep telefonunu hem de yaka kartını temizleme tercihi uygulamalarında hekim grupları arasında fark bulunmuyordu.

Sonuç: Hekimler mesleki kıdemi arttıkça daha fazla adette doktor önlüğüne sahip olmakta ancak yıkama alışkanlığı değişmemektedir. Cep telefonu ve yaka kartı gibi kişisel eşyaların temizlenmesi gerektiği konusunda farkındalık eksikliği vardır.

Anahtar Kelimeler: Cep telefonu, önlük, yaka kartı

\section{Correspondence Address/Yazışma Adresi}

Nevin Hatipoğlu

Sağlık Bilimleri Üniversitesi,

İstanbul Bakırköy Dr. Sadi Konuk Eğitim ve Araştırma Hastanesi,

Çocuk Enfeksiyon Hastalıkları Kliniği,

İstanbul-Türkiye

E-mail: naydin9@mynet.com 


\section{Introduction}

As in many professions, physicians also have a specific work uniform integrated culturally with its practices. "Doctor's white coat", as a work uniform, is perceived in the community as a symbol for goodness, cure, and purity $(1,2)$. Doctor's white coat can be a means of hospital infection filiation in terms of direct contact with the patients and contaminated surfaces.

Mobile phones are widely used in hospital settings for reasons of communication and information sharing. As a matter of fact, some physicians use two contact numbers and thus carry two mobile phones in their pockets. Following patient examination, the physician, inevitably and frequently, may have to touch his/her mobile phone with his/her contaminated hands without proper hand sanitation. Furthermore, there is no recommendation for a routine approach in mobile phone cleaning.

Name badge is a mandatory hospital item for proof of identity and for entering and exiting certain places requiring secure access. Despite not being directly in contact with the patient, name badges can be contaminated with the hands of the hospital personnel.

It has been confirmed that certain secondary equipment like doctor's white coat, mobile phones, and pens that physicians' use are colonized by various microorganisms at a rate of $47.5 \%$ (3).

The aim of this study was to investigate the attitudes and approaches of pediatricians regarding the cleaning of properties used in daily practice in hospitals including the doctor's white coat, mobile phone and name badge. A survey was used accordingly.

\section{Materials and Methods}

According to study protocol, pediatric infectious diseases specialist/subspecialist student, pediatrics/pediatric infectious diseases instructors (associate professor or professor) and pediatrics assistants working for at least 2 years filled out the survey questions. Seven multiple-choice questions not taking longer than a page were directed at the participants. The questions included the following: "How many white coats do you have?", "How often do you wash your white coats?", "How many mobile phones do you have?", "How do you clean your mobile phone(s) after leaving the hospital?", "Do you use name badges in your hospital?", "How do you carry your name badge?", and "Do you think that your name badge as a hospital item should be cleaned?". Moreover, the institution they work at and their academic status/title were also asked.

The survey was filled out by specialists and instructors when they all came together for a scientific meeting on pediatric infections, and pediatrics assistants filled out the survey during the gathering for clinical training at the same time and under observation so that the participants' impressionability possibility could be minimized.

Statistical analyses were performed on NCSS 11 (Number Cruncher Statistical System, 2017 Statistical Software) Program. Frequency and percentages were given for categorical variables. Chi-square test was used to analyze the relationship between two categorical variables. Fisher's Exact Test was used when appropriate. $\mathrm{P}<0.05$ was considered statistically significant.

\section{Results}

A total of 100 physicians were included into the study. Since the duration for the participants to answer the survey simultaneously and synchronously was limited and decreasing predictiveness was important, age/sex/employment duration were excluded from the study.

The largest group participating in the survey with 48 physicians was the pediatric infectious diseases specialist/subspecialist students. Instructors and pediatrics assistants comprised of 25 and 27 physicians, respectively. All instructors were pediatric infectious diseases subspecialists at the same time or were working predominantly in the pediatric infectious diseases field.

The table summarizes the distribution of response parameters as per academic status. Accordingly, although instructors and specialist physicians had more white coats compared to assistants $(p=0.005)$, the frequency of washing the white coat did not show any difference between the groups.

Each physician definitely used one mobile phone, and even in approximately one of 10 physicians possessed two mobile phones. There was no difference between the groups in terms of mobile phone cleaning preferences.

The use of name badges was mostly common in the assistant physician group $(p=0.02)$. On the other hand, applications of cleaning and carrying the name badge did not show a statistical difference.

More than $90 \%$ of the assistant physicians were working in training and research hospitals, and most of the instructors $(80 \%)$ were working in university hospitals.

\section{Discussion}

This study predominantly focused on the attitudes of specialists and instructors of pediatric infectious diseases and the physician group working at the early severance of pediatrics regarding the cleaning of personal hospital belongings.

Doctor's white coat is a professional work uniform worn for various reasons such as covering the clothes, carrying items, and keeping the person warm. It has been shown that bac- 
Table 1. The distribution of response parameters as per academic status

\begin{tabular}{|c|c|c|c|c|}
\hline Questions & $\begin{array}{l}\text { Instructor }{ }^{1} \\
n=25(\%)\end{array}$ & $\begin{array}{l}\text { Specialist }^{2} \\
\mathrm{n}=25(\%)\end{array}$ & $\begin{array}{l}\text { Asistant }{ }^{3} \\
n=27(\%)\end{array}$ & $\mathrm{p}$ \\
\hline \multicolumn{5}{|l|}{ How many white coats do you have? } \\
\hline 1 & $1(4)$ & $1(2.08)$ & $7(25.93)$ & $0.005^{*}$ \\
\hline 2 & $2(8)$ & $9(18.75)$ & $7(25.93)$ & \\
\hline 3 & $6(24)$ & $13(27.08)$ & $7(25.93)$ & \\
\hline More than 3 & $16(64)$ & $25(52.08)$ & $6(22.22)$ & \\
\hline \multicolumn{5}{|l|}{ How often do you was your white coat? } \\
\hline After wearing for $1-5$ times & $10(40)$ & $19(39.58)$ & $15(55.56)$ & $0.72^{*}$ \\
\hline After wearing for $6-10$ times & $9(36)$ & $20(41.67)$ & $7(25.93)$ & \\
\hline After wearing for 11-15 times & $4(16)$ & $6(12.5)$ & $4(14.81)$ & \\
\hline After wearing for $16-20$ times & $0(0)$ & $2(4.17)$ & $0(0)$ & \\
\hline After wearing for more than 20 times & $2(8)$ & $1(2.08)$ & $1(3.7)$ & \\
\hline \multicolumn{5}{|l|}{ How many mobile phones do you have? } \\
\hline One & $22(88)$ & $46(95.83)$ & $23(85.19)$ & $0.25^{*}$ \\
\hline Two & $3(12)$ & $2(4.17)$ & $4(14.81)$ & \\
\hline \multicolumn{5}{|l|}{ How do you clean your mobile phone after leaving the hospital? } \\
\hline I wipe it with a wet cloth every day when I come home & $10(40)$ & $15(31.25)$ & $3(11.11)$ & 0.09 \\
\hline I wipe it with antiseptic solution every day when I come home & $5(20)$ & $6(12.5)$ & $7(25.93)$ & \\
\hline I do not wipe it, it breaks down & $10(40)$ & $27(56.25)$ & $17(62.96)$ & \\
\hline \multicolumn{5}{|l|}{ Do you use name badges in your hospital? } \\
\hline No & $6(24)$ & $14(29.17)$ & $3(11.11)$ & 0.02 \\
\hline Yes, but it is not mandatory & $11(44)$ & $18(37.5)$ & $5(18.52)$ & \\
\hline Yes, it is needed for all procedures & $8(32)$ & $16(33.33)$ & $19(70.37)$ & \\
\hline \multicolumn{5}{|l|}{ How do you carry your name badge? } \\
\hline Clipped on & $7(28)$ & $13(27.08)$ & $5(18.52)$ & $0.41^{*}$ \\
\hline Wearing it around the neck & $5(20)$ & $10(20.83)$ & $10(37.04)$ & \\
\hline Hanging in my keychain & $1(4)$ & $1(2.08)$ & $2(7.41)$ & \\
\hline In my pocket & $7(28)$ & $14(29.17)$ & $6(22.22)$ & \\
\hline In my bag & $5(20)$ & $10(20.83)$ & $4(14.81)$ & \\
\hline \multicolumn{5}{|l|}{$\begin{array}{l}\text { Do you think that your name badge as a hospital item should be } \\
\text { cleaned? }\end{array}$} \\
\hline Yes & $16(64)$ & $26(54.17)$ & $10(37.04)$ & $0.35^{*}$ \\
\hline No & $2(8)$ & $6(12.5)$ & $6(22.22)$ & \\
\hline Never thought of it before & $7(28)$ & $16(33.33)$ & $11(40.74)$ & \\
\hline \multicolumn{5}{|l|}{ Your Institution } \\
\hline University hospital & $20(80)$ & $20(41.67)$ & $2(7.41)$ & $<0.0001$ \\
\hline Training and research hospital & $5(20)$ & $28(58.33)$ & $25(92.59)$ & \\
\hline \multicolumn{5}{|l|}{$\begin{array}{l}1 \text { Pediatrics/Pediatric Infectious Diseases Instructor. } \\
{ }^{2} \text { Pediatric infectious diseases specialist/subspecialist students. } \\
{ }^{3} \text { Pediatrics assistant. } \\
\text { Chi-Square Test. } \\
\text { *Fisher's Exact Test. }\end{array}$} \\
\hline
\end{tabular}


terial contamination of the white coat could reach $95 \%$ (4). Ninety-four (91.3\%) of the culture specimens taken from various parts of 103 doctor's white coats have been determined to be of contaminated with at least one bacterium(5). Doctor's white coat has been determined to be most frequently contaminated with diphtheroids, and it has been reported that infection agents related with severe healthcare issues, including Staphylococcus aureus (19.1\%), gram-negative bacilli (19.1\%), and Pseudomonas (9.6\%), have been isolated from the white coat (4). White coats of the physicians working in intensive care units have been found to be significantly contaminated $(28 \%)$ with S. aureus [including methicillin-resistant S. aureus (MRSA)](6). It is understood that doctor's white coat may substantially contain bacteria and play part in the transmission of nosocomial infections $(4,6,7)$. Hospital infections are a tremendous load for the pediatric infectious diseases specialty. Hence, not having found any difference between the specialists compromising $73 \%$ of the study group working in peditaric infectious dieseases as specialists and the assistants described as "novice" ( $p=0.72)$ points out that physicians in both groups overlook the fact that white coat causes nosocomial infections.

Usage habit of doctor's white coat vary as per internal and surgical medicine specialties $(6,8)$. White coats of the physicians of pediatrics are affected more by contamination, and the increase in the number of white coats the physician has and their daily wash habit decrease the possibility of contamination (5). This study also revealed that physicians, depending upon length of service, had more white coats. However, the assistant group with less white coats did not have the habit of washing their coats daily at a higher rate, which suggests that it should become a matter to be handled during assistant training.

Ideally, it is underlined that the white coat should be washed daily after contact with the patient or patient's environment, and if there is visible contamination on the coat, then it should be replaced by a clean one. Nonetheless, despite being contaminated with many hospital pathogens, doctor's white coat has not been demonstrated to be directly causing cross contamination with infection pathogens related with healthcare (1). The frequency of washing the white coat varies from physician to physician (9). Two thirds of the physicians state that they wash their coats less than once a week (6). More interestingly, a significant inconsistency regarding the period of use without washing the coat has been confirmed between the data obtained from the launderette of a hospital and the data acquired from the survey conducted on the physicians working in that said hospital, and the real median period of use of a white coat without getting washed has been found as 20 (range: 15-30) days (10). As it can be seen from the study we presented, seniority based on duration of employ- ment is not a distinguishing factor in the habit and frequency of washing the white coat. Although the manner of washing the white coat was not questioned in our survey, a practice of not washing hospital gowns and clothes with daily clothing is common among healthcare workers. On the contrary, an attitude of frequent change of white coat and washing these together was not observed among the specialist and instructor group who owned more than one white coat.

In addition, the possibility of contamination increases in the event of wearing the white coat at all times while in hospital compared to its clinical use only (5). Doctor's white coat, as a hospital uniform, is known to be responsible for the spread of healthcare-related infections $(4,6,7,9)$. Therefore, it is emphasized that physicians must remove their coats outside the clinic (in the cafeteria, library, meeting hall and similar places) and even during "patient examination" $(1,11)$. On the other hand, it has been indicated that with the current data at hand, hospital uniform cannot be stated as a means of infection contamination due to lack of evidence, and that uniforms should not be accepted as personal protective equipment. Moreover, contamination of the uniform does not essentially originate from the patient but from the user, the one who wears the coat, and an additional contamination takes place from the surroundings and the patient (12). It has been shown that knowledge status regarding uniform hygiene is at a medium-level among medical students, and correct use of occupational uniform should be added to the medical education in universities (13). The assistants, who need to stay in the hospital for longer hours due to full-day shift and frequent on-call duties, should be informed about the problems that could arise from the contamination of the white coat with vocational trainings.

The model of the white coat, whether it is short or long sleeved, does not have an impact on the frequency of contamination; however, long-sleeved white coats are contaminated with more S. aureus compared to short-sleeved coats $(4-7,14)$. In daily practice, physicians may prefer using the long-sleeved white coats by folding the long sleeves. This study did not question about the sleeve model of the white coat. Furthermore, some of the physicians prefer using their long-sleeved coats by folding the sleeves during the day. Therefore, the sleeve length of the white coat makes it difficult to capture homogeneity in the sleeve preference of the coat. Thus, it has been shown that there is not a striking difference between the standard doctor's white coat and short-sleeved hospital uniform in terms of bacterial colonization. In a prospective, randomized-control study, comparison of a standard doctor's white coat and a newly washed short-sleeved white coat in terms of bacterial contamination after an 8-hour shift has been made. Both uniforms have been proven to contain nearly $50 \%$ of bacterial (including MRSA) contamination at the end of a 3-hour use, and it has also been put forward that there is no distinctive difference 
between the newly washed and worn white coat and the rarely washed in terms of bacterial colonization ate the end of the 8-hour shift (15). The authors emphasize that there is no need to abolish the use of long-sleeved white coats and start wearing short-sleeved uniforms that are changed daily. Depending on this literature, it can be expressed that what is fundamental in the cleaning of hospital uniforms is not the model of the white coat but its frequent change and wash; however, the result of our study proved the opposite.

Although the Administration Regulations of Inpatient Treatment Institutions describe how doctor's white coats should be in our country, there are no written instructions on how to clean them (16). On the other side, experts recommend that physicians (healthcare personnel) should have at least 2 white coats and get them washed at least once a week (1). A remarkable detection in our study was that half of the assistant physicians participating in our study only had one or two white coats. In our country, doctor's white coat is a hospital item that physicians generally pay for from their own budgets. Physicians new to the occupation might be encouraged to obey by the necessary hygiene rules by providing the procurement of the white coat by the healthcare institution they work for.

Smart phones are contaminated more compared to other mobile phones, and pose risks for nosocomial infections especially in the intensive care units $(17,18)$. These items possess the favorable humidity and temperature for the bacteria to reproduce and act as reservoirs. Their colonization is between $10-100 \%$ and is most frequently contaminated by staphylococci (most commonly detected: S. aureus), and Acinetobacter strains are among the most frequently isolated gram-negative bacteria. Healthcare workers do not think that mobile phones can be contaminated and rarely disinfect their phones (19). As seen in our study, mobile phones were not regarded as items that should be cleaned by both the assistant and specialist and instructor groups.

A guideline towards the prevention of bacterial contamination of mobile phones in hospitals has not been published yet. Mobile phones can be disinfected by $70 \%$ isopropyl or ethyl alcohol. Bluetooth and use of antibacterial covers must be encouraged, and the production of waterproof and "washable" mobile phones should be brought to agenda. The literature mentions antibacterial nanomaterial covers, titanium materials, and UV sterilization techniques (19). Our observation is that awareness of the physicians must be increased regarding the fact that mobile phones are items that require cleaning.

According to the memorandum published by the General Directorate of Treatment Services of T.R. Ministry of Health, all personnel working in inpatient treatment institutions are obliged to wear a name badge (20). Despite this fact, usage ratio of the name badge among the pediatricians participat- ing from both university and training and research hospitals was not $100 \%$.

There is a difference in terms of bacterial contamination between the cords made up of fabric and metal. Metal cords are less likely to be contaminated by bacteria compared to fabric material. Coagulase negative staphylococci have been isolated the most. Only $16 \%$ of the healthcare workers have the habit of cleaning the cord. Cords made of fabric material should be decontaminated or switched to metal cords (21). Just as there is no standard for name badge models in our hospitals, there is no official regulation on the matter.

Name badges are mostly carried in pockets or wallets and may contain pathogenic bacteria. Bacteria can be transmitted from the badge to the screen and from the screen to the badge. Despite not in direct contact with the patient, name badges might be a reservoir and counted as an intermediate vector for hospital infections. As it can be understood from the study data, contamination potential in usage is permanent since physicians carry their badges in their pockets and bags apart from clipping them on or wearing them around the neck. It is recommended that name badges be cleaned with alcohol-based wipes, which are simple and cheap (22). As in mobile phones, a majority of the pediatricians -including pediatric infectious diseases specialists- do not clean their name badges which are part of hospital items ( $p=0.02)$, and there is lack of awareness.

In conclusion, physicians in various seniorities of pediatrics, including residency, specialty, and academicianship, have more white coats as their seniority and length of service increases. From a patient's point of view, usage of white coat provides a professional outlook and differentiates the physicians from other hospital personnel $(2,23)$. Mobile phone is a central item as a basic communication tool in the medical practice. Name badge is an institutional item that physicians must keep with themselves at all times. Regarding all of these personal items, necessary hygiene rules must be applied as strategies to prevent hospital infections, and awareness must be raised until official instructions are brought.

Ethics Committe Approval: It was considered that ethical approval is not required since the study is a questionnaire for adults.

Informed Consent: Since it is a questionnaire for adults, patient consent is not required.

Peer-review: Externally peer-reviewed.

Author Contributions: Concept-NH, AK; Design-NH, AK; Supervision: AK; Resource: NH, AK; Data Collection and/or Processing - NH, AK; Analysis and/or Interpretation - NH, AK; Literature Search - NH, AK; Writing - $\mathrm{NH}, \mathrm{AK}$; Critical Review - NH, AK.

Conflict of Interest: No conflict of interest was declared by the authors.

Financial Disclosure: The authors declared that this study has received no financial support. 


\section{References}

1. Bearman G, Bryant K, Leekha S, Mayer J, Munoz-Price LS, Murthy R, et al. Healthcare personnel attire in non-operating-room settings. Infect Control Hosp Epidemiol 2014;35:107-21. [CrossRef]

2. Tse G, Withey S, Yeo JM, Chang C, Burd A. Bare below the elbows: was the target the white coat? J Hosp Infect 2015;91:299-301. [CrossRef]

3. Pandey A, Asthana AK, Tiwari R, Kumar L, Das A, Madan M. Physician accessories: doctor, what you carry is every patient's worry? Indian J Pathol Microbiol 2010;53:711-3. [CrossRef]

4. Srinivasan M, Uma A, Vinodhkumaradithyaa A, GomathiS, Thirumalaikolundusubramanian $P$. The medical overcoat-is it a transmitting agent for bacterial pathogens? Jpn J Infect Dis 2007;60:121-2. [CrossRef]

5. Uneke CJ, ljeoma PA. The potential for nosocomial infection transmission by white coats used by physicians in Nigeria: implications for improved patient-safety initiatives. World Health Popul 2010;11:44-54. [CrossRef]

6. Treakle AM, Thom KA, Furuno JP, Strauss SM, Harris AD, Perencevich EN. Bacterial contamination of health care workers' white coats. Am J Infect Control 2009;37:101-5. [CrossRef]

7. Qaday J, Sariko M, Mwakyoma A, Kifaro E, Mosha D, Tarimo R, et al. Bacterial contamination of medical doctors and students white coats at Kilimanjaro Christian Medical Centre, Moshi, Tanzania. Int J Bacteriol 2015;2015:507890. [CrossRef]

8. Magos A, Maclean A, Baker D, Goddard N, Ogunbiyi O. Bare below the elbows: A cheap soundbite. BMJ 2007;335:684. [CrossRef]

9. Wong $D$, Nye K, Hollis P. Microbial flora on doctors' white coats. BMJ 1991;303:1602-4. [CrossRef]

10. Gouraud D, Dumont R, Asehnoune K, Lejus C. White coats: how long should doctors wear them? Ann Fr Anesth Reanim 2014;33:e23-5. [CrossRef]

11. Loh W, Ng VV, Holton J. Bacterial flora on the white coats of medical students. J Hosp Infect 2000;45:65-8. [CrossRef]

12. Wilson JA, Loveday HP, Hoffman PN, Pratt RJ. Uniform: an evidence review of the microbiological significance of uniforms and uniform policy in the prevention and control of healthcare-associated infections. Report to the Department of Health (England). J Hosp Infect 2007;66:3017. [CrossRef]
13. Jayarajah U, Athapathu AS, Jayawardane BAAJ, Prasanth S, Seneviratne $S N$. Hygiene practices during clinical training: knowledge, attitudes and practice among a cohort of South Asian Medical students. BMC Med Educ 2019;19:157. [CrossRef]

14. Muhadi SA, Aznamshah NA, Jahanfar S. A cross sectional study of microbial contamination of medical students' white coat. Malaysian Journal of Microbiology 2007;3: 35-38. [CrossRef]

15. Burden M, Cervantes L, Weed D, Keniston A, Price CS, Albert RK. Newly cleaned physician uniforms and infrequently washed white coats have similar rates of bacterial contamination after an 8-hour workday: a randomized controlled trial. J Hosp Med 2011;6:177-82. [CrossRef]

16. https://www.saglik.gov.tr/TR,10518/yatakli-tedavi-kurumlari-isletme-yonetmeligi-son-degisiklerle-beraber.html (güncelleme tarihi 20/10/2016; son erişim tarihi 4/6/2018). [CrossRef]

17. Lee YJ, Yoo CG, Lee CT, Chung HS, Kim YW, Han SK, et al. Contamination rates between smart cell phones and non-smart cell phones of healthcare workers. J Hosp Med 2013;8:144-7. [CrossRef]

18. Loyola S, Gutierrez L, Avendano E, Severino N, Tamariz J. Multidrug-resistant bacteria isolated from cell phones in five intensive care units: exploratory dispersion analysis. Germs 2018;8:85-91. [CrossRef]

19. Ulger F, Dilek A, Esen S, Sunbul M, Leblebicioglu H. Are healthcare workers' mobile phones a potential source of nosocomial infections? Review of the literature. J Infect Dev Ctries 2015;9:1046-53. [CrossRef]

20. http://www.trbism.gov.tr/images/files/mevzuat/genelgeler/saglik-hizmetleri/kiyafet-genelgesi.pdf (son erişim tarihi 4/6/2018) [CrossRef]

21. Pepper T, Hicks G, Glass S, Philpott-Howard J. Bacterial contamination of fabric and metal-bead identity card lanyards: a cross-sectional study. $\mathrm{J}$ Infect Public Health 2014;7:542-6. [CrossRef]

22. Sultan MJ, Alm A, Hindmarsh A, Greatorex RA. Security swipe cards and scanners are a potential reservoir for hospital-acquired infection. Ann R Coll Surg Engl 2009;91:155-8. [CrossRef]

23. Ardolino A, Williams LA, Crook TB, Taylor HP. Bare below the elbows: what do patients think? J Hosp Infect 2009;71:291-3. [CrossRef] 